\title{
CUSTOMERS' SWITCHING BEHAVIOR IN BANKING IN THE SPECIAL REGION OF YOGYAKARTA PROVINCE INDONESIA
}

\author{
Rofiul Wahyudi ${ }^{1}$
}

\begin{abstract}
Abstract

This study aims to provide influence on the customer's switching behavior in islamic banking in the special region of Yogyakarta Province, Indonesia. Design/Methodology/Approach

Multiple Regression were used to examine the influence of attitude towards switching, subjective norm, financial bonding, social bonding, structural bonding toward switching customers' behavior.

\section{Findings}

The result responses the variable of the attitude towards and subjective norm and financial bonding, social bonding, structural bonding significant to the switching intention to a conventional bank. Findings indicated it interaction between switching intention and customer satisfaction for customers' switching behavior.
\end{abstract}

\section{Research implication and recommendations}

Perhaps the most important finding of this research is those banking players particularly improvement customer satisfaction and identifying most factors driving intention to customers' switching.

Keyword

Customer satisfaction, customers' switching, switching customers' behavior

\footnotetext{
${ }^{1}$ Faculty of Islamic Studies, Islamic Banking Study Program, Ahmad Dahlan University (UAD) Yogyakarta. Email: rofiul.wahyudi@pbs.uad.ac.id
} 


\section{Introduction}

The existence of dual banking both conventional banks and sharia banks in generals have a strategic function as an intermediary and service providers in payment traffic. However, the characteristics of both types of banks can influence the behavior of prospective customers in determining their preferences for the selection of the two types of banks. Furthermore, customers' behavior on banking products in both conventional and sharia banks can be influenced by public attitudes and perceptions of the characteristics of the banking system itself.

The limited understanding and preference of the community is a challenge for the development of sharia banking services. The results of the Financial Services Authority (OJK) survey of the national financial literacy 2013 covering 20 provinces with 8,000 respondents provide an illustration of the low level of literacy among Indonesians. From the survey results, it was informed that only $21.8 \%$ of respondents who have the understanding, skills, and trust in using financial products and services, with a utilization rate of 59.7 percent. $^{2}$ Therefore, it is reasonable that the preference and level of use of sharia banking services are predicted to be still relatively low. This can be seen from the number of account users in Islamic banks $13,430,904$ accounts consisting of 182,409 current accounts, 12,896,014 savings accounts and deposits of 352,481 accounts (Kurnia, 2015). One of the factors affecting the condition is predicted to lie in the incentives for people to switch from conventional bank service products to sharia banking products. For the banking sector to have a better understanding of switching behavior, it is necessary to research on switching behavior more comprehensively.

General switching studies can be grouped into two groups: focus on consumer psychology and focus on bank attributes. Therefore, to make this research more comprehensive, this research focused on consumer psychology and bank attribute as well. Behavioral switching research uses many theories of planned behavior (TPB). This it because TPB is an integrated model consisting of four predictors of behavior, attitude, subjective norm, perceived behavioral control (PBC), and intention to behave (Ajzein and Driver, 1991). TPB itself is not an exclusive model for predicting intention or behavior. Ajzen states that TPB is flexible enough to include additional predictors that can explain significantly the variant of intention (Ajzein, 1991). Not surprisingly, some researchers then expanded on the TPB, among others by adding new predictors to predict behavioral intentions. Several studies that expanded TPB were conducted

\footnotetext{
${ }^{2}$ http://www.ojk.go.id/siaran-pers-ojk-gelar-kegiatan-edukasi-keuangan-di-yogyakarta
} 
by Stimsons and Warrens (2005), Hyde and White on organ donor behavior (2009). While Honkanen et al. (2006) and Karijn Bonne, et al. on food selection behavior (2007), Xu et al. (2013) on the behavior of online game switching. Due to the broad utilization of TPB, this study attempts to examine switching behavior in the banking sector by using an expanded TPB by adding variables that theoretically predictors of switching behavior

Yogyakarta is a city of education with many institutions of higher education and private so many students settled in this city. As known to the student is an agent of change, which can bring changes to the surrounding environment. As a city of education, the academic culture is very developed in Yogyakarta. Discussion forums, seminars, and workshops on Islamic banks are often held in this city, thus helping socialization efforts and community education on sharia banks Besides, The Special Region of Yogyakarta is one of the cities where Islamic Rural Bank (BPRS) that operate on the first sharia principles are BPRS Bangun Drajat Warga (in 1994) and also one of the earliest sharia banking cities operating under the Sharia Business Unit (UUS) scheme established in Indonesia, namely BNI Syariah (year 2000) ${ }^{3}$. Long history of The Special Region of Yogyakarta in the field of sharia banking, not surprisingly, the market share of sharia syariah bank of $7.72 \%$ in the highest position nationally (Ausyah, 2015). ${ }^{4}$

In particular, sharia banking in the first quarter of 2015 experienced a decrease reflected in sharia banking assets in the first quarter of 2015 contracted $23.43 \%$ (yoy) or 3.78 Trillion. This figure is much lower than the first quarter and IV 2014 which can grow by $67.6 \%$ (yoy) and $0.7 \%$ (yoy). The decline in the asset of sharia banking in DIY was also followed by the Financing to Deposit Ratio (FDR) of $77.78 \%$ decreasing compared to the previous quarter which was $81.93 \%$ but the FDR was still quite high compared to the level of the loan to deposit ratio (LDR) of DIY banking in general. While fund raising increased compared to the previous quarter amounted to $2.58 \%$ (year on year). ${ }^{5}$

This research is important because firstly, as part of building block of OJK effort in mapping the development potential of sharia bank in Indonesia, which is one of the implementations of blue print of sharia banking development precisely in the face of ASEAN Economic Community (AEC) 2020. Secondly, to improve the role of sharia banking in the context of national banking, so it is expected to enlarge the share of

\footnotetext{
${ }^{3}$ http://www.bnisyariah.co.id/en/sejarah-bni-syariah, accessed on a date 20 February 2016

${ }^{4}$ Peran OJK dalam Lembaga Jasa Keuangan Syariah

${ }^{5}$ http://www.bi.go.id/id/publikasi/kajian-ekonomi regional/yogya
} 
Islamic banking. Third as an effort to strengthen the foundation of an economic theory of Islam through the integration of Islamic Economics (Islamic Banking) with the general sciences (statistics) is growing. The purpose of this research is to analyze the relationship of switching intention and customer satisfaction toward switching behavior in sharia bank.

Based on the above discussion, the author is interested in studying to following issues:

1. Do attitudes toward attitude and subjective norm affecting customers' switching intention to the conventional bank?

2. Does financial bonding, social bonding, and structural bonding affect customer's satisfaction?

3. Do switching intention and customer satisfaction influence customer behavior intention switching to the conventional bank?

\section{Literature Review}

Research on switching provider has been done. In general, the research can be grouped into two clusters, first focus on such bank attributes as Matos, Henrique, and Rosa (2013), Lam et al. (2004), Keaveney (1995), Gerard and Cunningham (2000), Lees, et al. (2005). Second focus on consumer psychology as Lo and Liang (2009), Lin (2010), Xu et al. (2013), Takele and Sira (2013). Almost all research on switching behavior with a focus on consumer psychology uses the Theory of Planned Behavior (TPB). Its appropriately used to assess individual behavior, including switching behavior.

Ajzen and Fishbein (2000) argue that intention is a major component in TPB and a direct antecedent of behavior. Its mean that individuals tend to behave when they have opportunities; the stronger the intention to move, the greater the likelihood that the individual will perform switching behavior. Therefore, actual behavior can be predicted from its intentions, and it is not surprising that most of the research is more researching behavioral intentions than actual behavior. Some studies that prove the relationship of intention with behavior among others Kerr, Lennon, and Watson (2010), Manneti, Piero et al. (2012), Schwenk, G, and Möser.,(2009), Gao, Z et al. (2008).

The inclusion of previous experience variables and recency into the TPB model is the result of Bagozzi and Warshaw (1990) research that modified TPB into a theory they call the theory of trying. Some research on behaviors such as Miniard and Obermiller (1981), Woodside and Bearden (1981), Bentler and Speckart (1979) found that previous 
experiences were predictable variables of intent and behavior. Behavior that occurs which is preceded by the intention to behave is influenced by previous experience (behavior) either directly or indirectly. So the intention and behavior of switching will be positively influenced by previous experience. While recency is a transaction that just happened. According to Bagozzi and Warshaw (1990), recency has a direct influence on behavior.

Attitude towards switching is a hypothetical construct that represents one's likes or dislikes for switching in a bank. Attitudes towards switching may change due to experience, stimulus and so on. Fishbein and Ajzen (2000) say that attitudes toward switching, independently, are difficult to use to predict switching behavior. Therefore, combining other variables with attitudes can predict a person's switching behavior better than just one variable. Several studies that demonstrate attitudes related to behavior include Xiao and Wu (2006), Rutherford and DeVaney (2009), Majali and Nik Mat (2010), Ok and Shon (2010), Amin and Ramayah (2011) and others. Bansal and Taylor (1999), found that attitudes toward switching (attitude toward switching) have a significant effect on switching intentions.

Subjective norms are a non-psychological factor in TPB. This subjective norm is a factor outside the individual who is thought to be the antecedent of switching intention or switching behavior. Some call this subjective norm as a social factor of encouragement, suggestion or suggestion to perform specific behaviors. Some studies that prove the role of subjective norms in shaping behavior include Majali and Mat (2010), Alleyne and Broome (2011), Beiginia, et al. (2011), Aziz (2012), etc. However, the strength of the sub-ethical relationship of relationships with behaviors varies from one research locus to the other locus, some of which show strong relationships, some of which show weak relationships.

The next collapse is customer satisfaction. Research on the importance of customer satisfaction in banking has been widely used such as: Naser et al. (1999), Metawa and Almossawi (1998), Boyd et al. (1994), Othman and Owen (2003), Polatoglu and Ekin (2001), Gounaris et (2003), Yavas et al. (2004), Bielski (2004). Lubin (1992) emphasizes that customer satisfaction and customer's willingness to survive (customer retention) are highly relevant and very important in the banking industry. Satisfied customers will convey a positive message about the quality of the service to others, and minimize the possibility of customers moving to another bank. Customer satisfaction is also influenced by consumer bonding. 
Consumer bonding is part of relationship marketing, which consists of financial bonding, social bonding, and structural bonding. Smith (1998) found that financial bonding can increase consumer satisfaction. Several other studies have also found a positive relationship between consumer bonding and satisfaction such as Palmatier, Gopalakrishna, and Houston (2006), Wang, Liang and Wu (2006). Consumers who are satisfied will be loyal to the bank used. Several other studies have also found that consumers who have close relationships with service providers are less likely to switch providers, such as Bove and Johnson (2000), Li, Browne, and Wetherbe (2007).

Research model can be described as follows:

Table 1

Research model

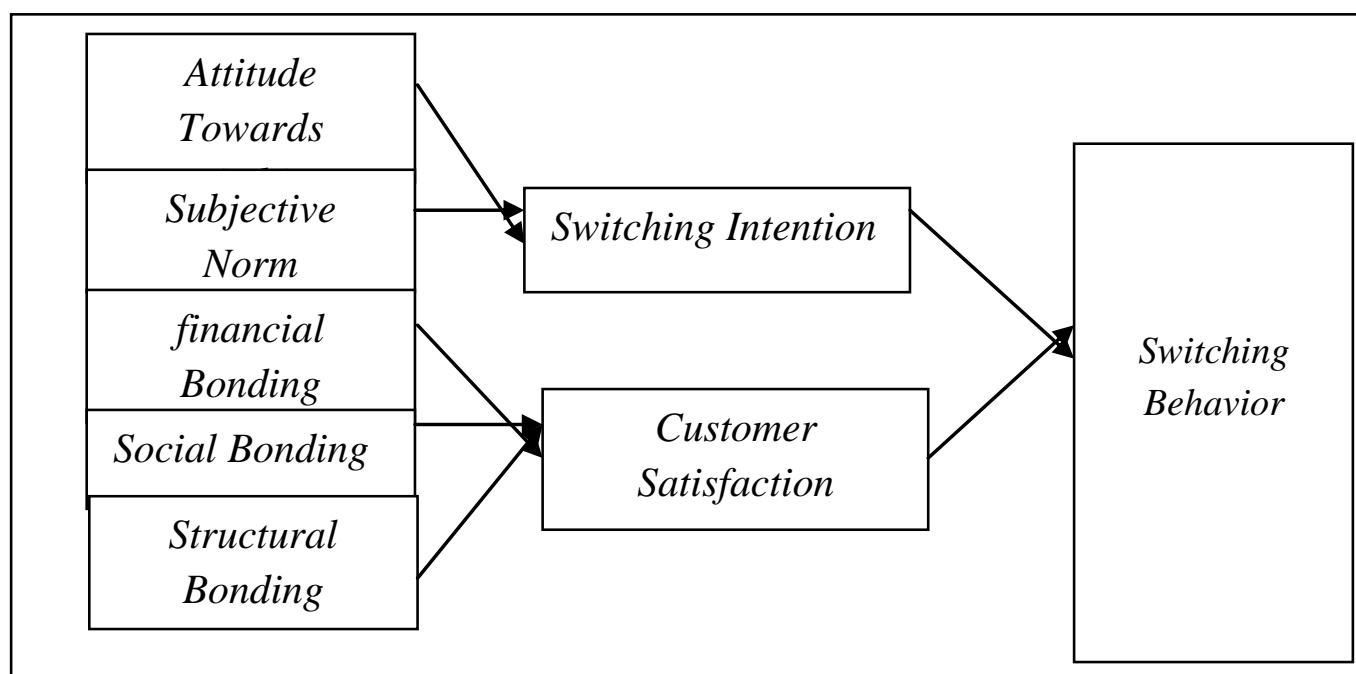

To give direction for this research hence proposed a hypothesis. Based on literature review and previous research, the hypothesis in this research are:

1. $\mathrm{H}_{1}$ : Attitude towards switching influences the customer's intention to conventional bank

2. $\mathrm{H}_{2}$ : Subjective norm influences the customer's intention to conventional bank

3. $\mathrm{H}_{3}$ : financial bonding influences on customer satisfaction

4. $\mathrm{H}_{4}$ : Social bonding influences on customer satisfaction.

5. $\mathrm{H}_{5}$ : Structural bonding influences on customer satisfaction

6. $\mathrm{H}_{6}$ : switching intention and customer satisfaction influence customer behavior intention switching to conventional bank 


\section{Methodology}

1. Research Method

The purpose of the study is to examine factors that drive customers switching behavior in the islamic bank. General switching studies can be grouped into two groups: focus on consumer psychology and focus on bank attributes. Therefore, to make this research more comprehensive, this research is focused on consumer psychology and bank attribute as well.

Based on the switching literature review conducted, the study identified, first, switching intention they are the attitude towards switching and subjective norm. Second, customer satisfaction they are financial bonding, Social bonding, and structural bonding

2. Research object and Population

The province is divided into one city of Yogyakarta and four regencies: Sleman, Bantul, Kulon Progo and Gunung Kidul. According to data issued by Otoritas Jasa Keuangan (OJK) in 2016, there is 24 banks are 12 Bank Umum Syariah (BUS), Unit Usaha Syariah (UUS) and 12 Bank Pembiayaan Rakyat Syariah (BPRS).

3. Sampling and Data Collection

Design of samples are purposive proportional sampling by considering following aspects (a) sharia bank customers who have financing accounts and/or savings / current accounts/deposits, (b) work as employees (private and civil servants) and retirees based on Priorities and targets \& activities of financial literacy (c) domiciled in DIY. The researcher decided to take 150 questionnaires were distributed to the respondent, however, after selecting those questionnaires, only 148 were usable to further analysis.

4. Technique of Analysis

This study uses a questionnaire consisting of several parts. The first part contains the demographic profiles of respondents and screening questions such as whether they want to move conventional banks. The second part contains the reasons that led to wanting to move to a conventional bank. The third section contains psychological profiles of respondents consisting of switching intention, attitude toward switching, subjective norm, customer satisfaction, and customer bonding. Then tested the validity and reliability of the questionnaire to show that all items in this study are valid and all items in the questionnaire of this study stated reliable. 
Hypothesis test of this research using descriptive statistics and simple linear regression which includes partial test (t-test), test $F$ (Test F) and Test coefficient of determination $\left(\mathrm{R}^{2}\right)$.

\section{Result and Analysis}

I. Profile of the respondent

Four main data related the respondents are their age, gender, level of education and their primary work or business.

1. Gender

Table 1 below shows the distribution of respondents regarding gender, as follows:

Table 1. Gender of Respondents

\begin{tabular}{ccc}
\hline Item & Frequency & $\begin{array}{c}\text { Percentage } \\
(\%)\end{array}$ \\
\hline Male & 63 & $42.6 \%$ \\
Female & 85 & $57.4 \%$ \\
Total & 148 & 100 \\
\hline
\end{tabular}

Table 1 shows that the respondents comprise 42.6 percent of males accounted for 57.4 percent of females.

2. Age

Table 2 below shows the distribution of respondents regarding ages, as follows:

\begin{tabular}{lcc}
\multicolumn{3}{c}{ Table 2. Age of Respondents } \\
\hline Item & Frequency & $\begin{array}{c}\text { Percentage } \\
(\%)\end{array}$ \\
\hline Less than 25 years & 18 & $12.2 \%$ \\
Between 26-35 years & 25 & $16.9 \%$ \\
Between 36-45 years & 52 & $35.1 \%$ \\
Between 46-55 years & 32 & $21.6 \%$ \\
More than 56 years & 21 & $14.2 \%$ \\
Total & 148 & 100 \\
\hline
\end{tabular}

As can be seen, 35.1 percent or most of them are in between 36 - 45 years old, 21 percent are between 46 -55 years old. However, when it is reviewed, the distributions are reasonably or ordinarily divided.

3. Education level 
Tabel 3. Education Level of Respondents

\begin{tabular}{lcc}
\hline Item & Frequency & $\begin{array}{c}\text { Percentage } \\
(\%)\end{array}$ \\
\hline Diploma & 14 & $9.5 \%$ \\
Bachelor Degree & 115 & $77.7 \%$ \\
Master \& Ph.D & 19 & $12.8 \%$ \\
Total & 148 & 100 \\
\hline
\end{tabular}

Eventually, most of them are graduates of Bachelor Degree (77\%), although the second majorities are the Master and Ph.D. (12.8\%). $9.5 \%$ are graduates of Diploma.

4. Employment background

Tabel 4. Type of employment background

Item

$\begin{array}{cc}\text { Frequenc } & \text { Percentag } \\ \mathrm{y} & \mathrm{e}\end{array}$

Civil Servants (Government employees) Employees of State Owned Companies 76 53 $51.4 \%$

Retired 19

Total
$35.8 \%$ $12.8 \%$ 100

According to the Priorities and targets \& activities of financial literacy Otoritas Jasa Keuangan (OJK), Most of the selected respondents have been established civil servants (Government employees) 51.4 percent, employees of state-owned companies 35.8 percent and retired 12.8 percent.

5. Status

Tabel 5. Status of Respondents

\begin{tabular}{lcc}
\hline \multicolumn{1}{c}{ Item } & Frequency & $\begin{array}{c}\text { Percentage } \\
(\%)\end{array}$ \\
\hline Single & & $11.5 \%$ \\
Marriage & 17 & $88.5 \%$ \\
Total & 131 & 100 \\
\hline
\end{tabular}

The table 5 shows that status of respondents most of them are marriage 88.5 percent 11.5 percent are single of the sample.

6. Income 
Tabel 6. Income of Respondents

\begin{tabular}{lcc}
\hline Item & Frequency & $\begin{array}{c}\text { Percentage } \\
(\%)\end{array}$ \\
\hline Less than 1.500 .000 & 16 & $10.8 \%$ \\
Between $1.600 .000-3.000 .000$ & 44 & $29.7 \%$ \\
Between $3.100 .000-4.500 .000$ & 57 & $38.5 \%$ \\
Between $4.600 .000-6.000 .000$ & 22 & $14.9 \%$ \\
More than 6.000.000 & 9 & $6.1 \%$ \\
Total & 148 & 100 \\
\hline
\end{tabular}

The above table also confirms that most of the income level respondents 38.5 percent income level between 3.100 .000 4.500.000 per month, between $1.600 .000-3.000 .000$ has $29.7 \%$. This finding indicates that most of the respondents can be identified as the middle-class income.

7. Bank Relationship

Tabel 7. Bank Relationship of Respondents

\begin{tabular}{lcc}
\hline Item & Frequency & $\begin{array}{c}\text { Percentage } \\
(\%)\end{array}$ \\
\hline$<2$ year & 23 & $15.5 \%$ \\
3-4 year & 56 & $37.8 \%$ \\
5-6 year & 44 & $29.7 \%$ \\
> 6 year & 25 & $16.9 \%$ \\
Total & 148 & 100 \\
\hline
\end{tabular}

Most of the selected bank relationship as respondents have been established between $3-4$ years $(37.8 \%)$ and has less bank relationship are below two years (15.5\%).

II. Screening questions

1. Intent to switching to conventional banks of respondents Tabel 8. Intent to switching to conventional banks of Respondents

\begin{tabular}{lcc}
\hline \multicolumn{1}{c}{ Item } & Frequency & $\begin{array}{c}\text { Percentage } \\
(\%)\end{array}$ \\
\hline Not Yet & 122 & $82.4 \%$ \\
Yes & 26 & $17.6 \%$ \\
Total & 148 & 100 \\
\hline
\end{tabular}

As the screening questions whether they intent to switching to conventional banks show that that 82.4 percent not yet and 17.6 percent. It is why it is also interesting to follow up this early finding. 
2. Argue intention to switch

Tabel 9. Argue intention to switch of respondents

\begin{tabular}{lll}
\hline \multicolumn{1}{c}{ Item } & Frequency & \multicolumn{1}{c}{$\begin{array}{c}\text { Percentage } \\
(\%)\end{array}$} \\
\hline Customer satisfaction & 26 & $16.1 \%$ \\
Service quality & 34 & $21.1 \%$ \\
Sharia compliance & 21 & $13 \%$ \\
Pricing & 67 & $41.6 \%$ \\
Total & 148 & 100 \\
\hline
\end{tabular}

The above table confirms that argue intention to switch respondents said that pricing $41.6 \%$ percent, customer satisfaction 16.1 percent, service quality 21.1 percent and sharia compliance 12 percent.

\section{Finding Analysis}

1. Reliability analysis (Cronbach's Alpha)

The main idea contained in the concept of reliability is the extent to which the results of a measurement can be trusted. According to Azwar The coefficient alpha for each variable exceeded the minimum standard of 0.60 which is acceptable in similar theory building (Vyas \& Raitani, 2014).

Empirically, the high and low reliability are shown by a number called the reliability coefficient. Theoretically, the magnitude of the reliability coefficient ranges from 0 to 1 . The reliability coefficient is getting closer to 1 means the more reliable (Azwar, 2013).

Tabel 10. Reliability analysis (Cronbach's Alpha)

\begin{tabular}{|l|c|c|}
\hline \multicolumn{1}{|c|}{ Variable } & No. Of Items & Cronbach's Alpha \\
\hline Attitude Towards & 4 & 0,9323 \\
\hline Subjective norm & 2 & 0,9515 \\
\hline Financial bonding & 2 & 0,9783 \\
\hline Social Bonding & 2 & 0,7983 \\
\hline Structural Bonding & 4 & 0,8184 \\
\hline
\end{tabular}

Resource: Primary data, processed (2017)

The above table concluded that all the statements are reliable and consist. The higher value of Cronbach's alpha coefficient is financial bonding 0,9783 and the less value social bonding 0.7983. It's the reliability of attitude towards (four item), 
subjective norm (two item), financial bonding (two item), social bonding (two item), and structural bonding (four item).

2. Descriptive Statistics

As shown in the below table, the descriptive statistics of the each variable. Attitude towards, subjective norm, financial bonding, and social bonding have a mean value ranging 3.5768 to 3.3.8876. it is shown that respondent considered all of this variable are important. Otherwise, structural bonding is below three. Its mean that customers were mostly to disagree with the variable.

Tabel 11. Descriptive Statistics

\begin{tabular}{|l|c|c|}
\hline \multicolumn{1}{|c|}{ Description of Variable } & Mean & $\begin{array}{c}\text { Std. } \\
\text { Deviation }\end{array}$ \\
\hline Attitude Towards & 3.8876 & 0.65567 \\
\hline Subjective norm & 3.7953 & 0.65905 \\
\hline Financial bonding & 3.5768 & 0.66447 \\
\hline Social Bonding & 3.7546 & 0.63333 \\
\hline Structural Bonding & 2.6543 & 0.62335 \\
\hline
\end{tabular}

Resource: Primary data, processed (2017)

3. Regression Estimation

To investigate factors driving switching intention (attitude towards and subjective norm) and customer satisfaction (financial bonding, social bonding, and structural bonding) to switching behavior the study used Pearson's correlation.

These correlations and their statistical significant are given in the table below. As can be seen variable attitude towards, subjective norm, financial bonding, social bonding and structural bonding have a positive and significant relationship with switching behavior of the banking customers at 0.01 and 0.05 level respectively. Therefore, all this result provide support customer satisfaction and switching intention to predict the likelihood of switching behavior in the islamic banking. 
Tabel 12. Pearson's Correlation

\begin{tabular}{|l|r|}
\hline \multicolumn{1}{|c|}{ Description of Variable } & Switching Behavior \\
\hline Attitude Towards & $.921^{* *}$ \\
& .000 \\
\hline subjective norm & $.862^{* *}$ \\
& .000 \\
\hline Financial bonding & $.695^{*}$ \\
& .000 \\
\hline Social Bonding & $.749^{* *}$ \\
& .000 \\
\hline Structural Bonding & $.862^{*}$ \\
& .000 \\
\hline Notes: & \\
${ }^{* *}$ Correlation is significant at the & \\
0.01 level (2-tailed) & \\
${ }^{*}$ Correlation is significant at the & \\
0.05 level (2-tailed) & \\
\hline
\end{tabular}

Resource: Primary data, processed (2017)

4. Regression Estimation

To investigate factors driving switching intention (attitude towards and subjective norm) and customer satisfaction (financial bonding, social bonding, and structural bonding) to switching behavior the study used analysis regress berganda dengan model econometric sebagai berikut:

It mean:

$$
Y=b_{0}+b_{1} X_{1}+b_{2} X_{2}+b_{3} X_{3}+b_{4} X_{4}+b_{5} X_{5}
$$

$Y$ : Switching Behavior

$\mathrm{X}_{1}$ : Attitude towards

$\mathrm{X}_{2}$ : Subjective norm

$X_{3}$ : Financial bonding

$\mathrm{X}_{4}$ : Social bonding

$X_{5}$ : Structural bonding

The following test results multiple regression analysis: 
Tabel 13. Test results in multiple regression analysis

\begin{tabular}{|l|l|l|l|l|}
\hline \multicolumn{1}{|c|}{ Variable } & \multicolumn{1}{|c|}{ B } & Std.Error & t value & Sig. $t$ \\
\hline Attitude towards & 0.795 & 0.295 & 2.696 & 0.008 \\
\hline Subjective norm & 0.529 & 0.119 & 4.443 & 0.000 \\
\hline Financial bonding & 0.903 & 0.244 & 3.669 & 0.002 \\
\hline Social bonding & 0.493 & 0.317 & 2.659 & 0.000 \\
\hline Structural bonding & 0.730 & 0.216 & 3.523 & 0.001 \\
\hline Konstanta & 2.116 & & & \\
\hline R & 0.725 & & & \\
\hline R Square & 0.526 & & & \\
\hline F & 25.197 & & & \\
\hline Sig.F & 0.000 & & &
\end{tabular}

Based on the results of multiple regression analysis can be explained as follows:

1. Partial Test (t-test)

a. The test results obtained $t$ count value of 2.696 with a sig. $t$ of $0.008(p<0.05)$. These results indicate that attitude toward switching has a significant effect on customers' intention to the conventional bank.

b. The test results can be seen $t$ count value of 4.443 with the sig. $t$ of $0.000(p<0.05)$ for the subjective norm variable. These results indicate that there is a significant influence between the subjective norm (subjective norm) on the client's intention to the conventional bank.

c. The value of $t$ count of 3.669 with a sig. $t$ of $0.002(p<0.05)$ for the financial bonding variable. These results indicate that there is a significant influence between financial bonding effect on customer satisfaction.

$d$. The value of $t$ arithmetic of 2.659 withlslamicsig. $t$ equal to $0,049(p<0,05)$ for social bonding variable. These results indicate that there is a significant influence on social bonding effect on customer satisfaction.

e.

$f$. The value of $t$ count is 3.523 with a sig. $t$ of $0.001(p<0.05)$ for the structural bonding variable. These results indicate that there is a significant influence on structural bonding effect on customer satisfaction.

2. Test $F$ 
The value of test $F$ is 25.197 with the sig level. $0.000(p<0.05)$ which means the results of this study indicate that switching intention and costumer satisfaction effect on the behavior of customers to move to conventional banks.

3. Koefisien Determinasi $\left(R^{2}\right)$

Test results obtained a value of determination coefficient of 0.526 which means that attitude toward switching, subjective norms, financial bonding, social bonding and structural bonding contribute $52 \%$ while the remaining $48 \%$ is influenced by other variants outside the model.

\section{Conclusion and Recommendation}

The research has successfully answered the main propositions proposed earlier. First, the attitude towards switching has a significant effect on the customer's intention to move to a conventional bank. The results of this study are in line with Bansal and Taylor (1999), found that it has a significant influence on the switching intention. Second, there is a significant influence on the individual norm customers' intentions to move to a conventional bank. The results of this study are in line with research by Echchabi and Wahyuni (2010), Majali and Mat (2010), Alleyne and Broome (2011), Beiginia, et al. (2011), Aziz (2012) et.al.

Third, financial bonding, social bonding affect the customer satisfaction and structural bonding effect on customer satisfaction. Smith (1998) found that financial bonding can increase consumer satisfaction. Several other studies have also found a positive relationship between consumer bonding and satisfaction such as Palmatier, Gopalakrishna, and Houston (2006), Wang, Liang and Wu (2006). Consumers who are satisfied will be loyal to the bank used. Several other studies have also found that consumers who have close relationships with service providers are less likely to switch providers, such as Bove and Johnson (2000), Li, Browne, and Wetherbe (2007). Fourth, the results of this study indicate that switching intention and customer satisfaction affect the behavior of customers to move to conventional banks.

According to our findings, we suggest that the islamic banks should focus more on improving their managerial performance rather than on increasing the scale of operations to support the development of islamic banking in the Special Region Yogyakarta. 


\section{Bibliography}

Abduh M, Omar, MA., "Who Patronises Islamic Banks in Indonesia," Australian Journal of Islamic Law, Management, and Finance, Vol. 1, No. 1, 2010.

Abduh M., Kassim S., and Dahari Z., "Customer Satisfaction and Switching Behavior in Islamic Banking: Evidence from Indonesia Islamic School of Doctoral Studies (European Union) Journal, 2012.

Abduh, Muhamad, Withdrawal Behavior Of Malaysian Islamic bank Customers: Empirical Evidence from three Major Issues, Journal Of Islamic Banking And Finance, 2014.

Ajzen, I., \& Fishbein, M, "The Prediction Of Behavioral Intentions In A Choice Situation," Journal of Experimental Social Psychology, No.5, 1969.

Ajzen, I, Attitudes, Personality and Behavior, 2nd Edition, New York: Open University Press McGraw-Hill Education, 2005.

Ajzen., Icek, "The Theory Of Planned Behavior," Journal of Organizational Behavior And Human Decision Processes, No. 50, 1991.

Ajzen, I., \& Fishbein, M, "Attitudes And The Attitude-Behavior Relation: Reasoned And Automatic Processes," European Review Of Social Psychology, Vol. 1, No. 11, 2000.

Ajzen, I., \& Driver, B. L. "Prediction Of Leisure Participation From Behavioral, Normative, And Control Beliefs: An Application Of The Theory Of Planned Behavior," Leisure Sciences, No.13, 1991.

Burnett, Tim, The Impact Of Service Bundling On ConsumerSwitching Behaviour: Evidence From UKCommunication Markets, Working Paper No. 14/321, April 2014.

Bollen, Kenneth A. and Noble, Mark D., "Structural Equation Model and the Quantification of Behavior," Paper Colloquium of the National Academy of Sciences, "Quantification of Behavior," Washington, June 11-13, 2010.

Celso Augusto de Matos, Jorge Luiz Henrique, and Fernando de Rosa, "Customer Reactions To Service Failure And Recovery In The Banking Industry," Journal of Services Marketing, Vol. 27, No. 7, 2013.

Clemens, Michael D., Gan Christopher, and Zheng, Li Yan, "Customer switching behavior in the New Zealand banking industry," Banks and Bank Systems, Vol. 2, Issue 4, 2007. 
Chin, W.W., The Partial Least Square Approach for Structural Equation Modelling, Cleveland, Ohio, 1998.

Jyue-Yu Lo \& Fu-Mei Liang Study Of Service-Provider Switching Behaviors, Journal Of Management Reviews, Vol. 30, 2011.

Gerrard, Philip, and Cunningham J. B., Consumer Switching Behaviour in The Asian Banking Market, The Journal of Services Marketing, Vol. 18, No. 2, 2004.

Hair, Joseph F., Hult, M, Ringle, Christian, and Sarstedt, Marko, on partial least squares structural equation modeling ( PLS-SEM), Sage Publications Inc., Singapore, 2014.

Kiser, Elizabeth K., "Household Switching Behavior at Depository Institutions: Evidence from Survey Data," Antitrust Bulletin; Vol. 47, No. 4, 2002

Keaveney, Susan M, "Customer switching behavior in service industries: An exploratory study," Journal of Marketing, Vol. 59, No. 2, 1995.

Lees, G., Garland, R., Wright, M., "Brand Switching in New Zealand Retail Banking," ANZMAC 2005 Conference: Services Marketing, 2005.

Subramaniam, Ramaiyer, Ramachandran, Jayalakshmy,"Customers' Switching Behavior In Banking Industry-Empirical evidence from Malaysia," International Journal of Business, Economics and Law, Vol. 1, 2012.

Wirtz, J., Xiao, Ping, Chiang, Jeongwen and Malhotra, Naresh, Contrasting the Drivers of Switching Intent and Switching Behavior contractual Service Settings, Journal of Retailing, Vol. 90, No. 4, 2014.

Takele, Yitbarek, and Sira, Zeleke, Analysis Of Factors Influencing Customers' Intention To The Adoption Of E-Banking Service Channels In Bahir Dar City: An Integration Of Tam, TPB, And Pr, European Scientific Journal, Vol.9, No.13, 2013.

Vincenzo Esposito Vinzi, Wynne W. Chin, Jörg Henseler, Huiwen Wang, Handbook of Partial Least SquaresConcepts, Methods and Applications, Berlin: Springer, 2010.

Xiaoyu Xu, Hongxiu Li, Jukka Heikkilä, Yong Liu, Exploring Individuals' Switching Behaviour: An Empirical Investigation In Social Network Games In China, 26th Bled It Innovations: Challenges And Impacts For Individuals, Organizations, And Society, June 9, 2013 - June 13, 2013; Bled, Slovenia

Yin, Weilslamicand Matthews, Kent, "Why do firms switch banks? Evidence from China", Working Paper No. E2014/17, 2014. 